\title{
PENGARUH INFESTASI VERTICILLIUM LECANII TERHADAP KEPARAHAN PENYAKIT KARAT DAUN KOPI PADA TANAMAN DAN KETERJADIAN KOLONINYA PADA DAUN
}

\author{
Cipta Ginting ${ }^{1}$
}

\begin{abstract}
ABSTRAK
Effect of infestation of Verticillium lecanii on the severity of coffee leaf rust on plants and the incidence of its colony on coffee leaves. $V$. lecanii often antagonizes $H$. vastatrix on lesions caused by the pathogen on coffee leaves in the field. The objectives of this study were to evaluate the efficacy of $V$. lecanii to control disease severity on coffee plants in a green house and to compare the incidence of $V$. lecanii colonies on coffee leaves naturally infested by $V$. lecanii in the field and that in the leaves with additional infestation in the laboratory. For efficacy test and additional infestation in the laboratory, conidia were harvested from YMPD medium. Suspension with $10^{7}$ conidia $\mathrm{ml}^{-1}$ was sprayed into coffee foliage until both surfaces of the leaves were saturated with the suspension. After the leaves were air dried, they were sprayed with urediospores $\left(10^{4} \mathrm{ml}^{-1}\right)$. The results show that disease severity in plants treated with $V$. lecanii and control plants was not significantly different $(P \leq 0.05)$, except that obtained at the fourth week when disease severity on the treated plants was significantly lower that that in control plants. The number of $V$. lecanii colonies on coffee leaves naturally infested with the biocontrol agent was not increased by additional infestation with $V$. lecanii conidia in the laboratory.
\end{abstract}

Key words: Verticillium lecanii, Hemileia vastatrix, coffee leaf rust, mycoparasitism

\section{PENDAHULUAN}

Permasalahan utama dalam perkopian nasional ialah rendahnya mutu kopi secara umum sehingga kurang bersaing di pasaran internasional. Penyebab utamanya ialah bahwa jenis yang diproduksi didominasi oleh kopi robusta (Coffea canephora Pierre var. robusta Cheval.), sedangkan yang lebih disukai ialah arabika (Coffea arabica L.) karena citarasanya lebih baik. Untuk meningkatkan mutu kopi, telah diperluas penanaman kopi arabika di Indonesia termasuk di Provinsi Lampung.

Salah satu kendala pokok program ini ialah penyakit karat daun yang disebabkan oleh Hemileia vastatrix B. Br. Pengendalian penyakit secara kimia dengan berbagai fungisida mahal dan dapat menimbulkan dampak negatif terhadap kesehatan dan lingkungan serta kadang-kadang tidak efektif jika lingkungan mendukung perkembangan penyakit. Oleh karena itu, perlu ditemukan cara pengendalian yang efektif sekaligus efisien dan aman seperti pemanfaatan jamur antagonis Verticillium. Beberapa laporan (a.l., Mawardi, 1996; Ginting \& Mujim, 2005) menunjukkan bahwa Verticillium sering memarasiti H. vastatrix. Verticillium hidup dari uredospora dan uredium patogen (Mawardi, 1996; Ginting et al., 2002; Yun et al., 1991). Dengan demikian,
Verticillium berpotensi untuk mengurangi potensi inokulum. Hal ini diharapkan mengurangi keterjadian penyakit (disease incidence) karena telah diketahui bahwa kepadatan uredospora mempengaruhi keterjadian penyakit (Semangun, 2000).

Dalam patosistem penyakit karat daun kopi, uredospora sebagai inokulum sekunder merupakan penyebab parahnya penyakit. Infeksi primer biasanya kurang berpengaruh, namun akan menghasilkan inokulum sekunder berupa uredospora tersebut. Jika populasi antagonis Verticillium tinggi pada daun dan memarasiti uredia dan uredospora, maka kepadatan uredospora (inkulum sekunder) akan menurun sehingga infeksi sekunder juga akan menurun secara drastis (Agrios, 2005; Semangun, 2000). Dengan demikian, fungisida tidak akan perlu diaplikasikan untuk mengendalikan penyakit karat daun pada kopi.

Ginting et al. (2005) telah mengisolasi dan mengidentifikasi Verticillium dari kebun kopi di Lampung Barat sebagai $V$. lecanii. Sebagian data hasil uji efikasi $V$. lecanii untuk mengendalikan keterjadian penyakit di laboratorium menunjukkan bahwa $V$. lecanii secara nyata menurunkan keterjadian penyakit pada cakram daun kopi, namun terdapat juga data yang menunjukkan bahwa pengaruhnya tidak nyata (Ginting \& Mujim, 2007). Data yang menunjukkan keefektifan $V$. lecanii ini sejalan dengan

\footnotetext{
${ }^{1}$ Jurusan Proteksi Tanaman, Fakultas Pertanian, Universitas Lampung Jl. Prof. Soemantri Brodjonegoro No. 1 Bandar Lampung 35145
} 
laporan sebelumnya (Askary et al., 1997; Kiss, 2003; Mujim et al., 2005; Benhamou \& Brodeur, 2000) tentang potensi $V$. lecanii sebagai agensia hayati untuk mengendalikan penyakit tanaman. Pada penelitian sebelumnya (Ginting \& Mujim, 2007), uji efikasi dilakukan pada bagian tanaman yaitu cakram daun kopi. Mengingat bahwa sebagian percobaan sebelumnya (Ginting \& Mujim, 2007) menunjukkan keefektifan $V$. lecanii untuk mengendalikan penyakit karat daun kopi di laboratorium, penelitian perlu dilanjutkan dengan menguji efikasi agensia hayati ini pada tanaman utuh di rumah kaca.

Jika uji efikasi di rumah kaca berhasil, tahapan kegiatan selanjutnya ialah uji efikasi di lapangan. Sebelum pengujian di lapangan, perlu diketahui apakah di laboratorium terjadi peningkatan penekanan patogen oleh agensia hayati dengan melakukan infestasi buatan di laboratorium dibandingkan dengan infestasi alami saja. Untuk itu, perlu dibandingkan antara keterjadian koloni $V$. lecanii pada daun kopi yang terjadi secara alami di lapangan dan keterjadian koloni pada daun kopi yang diinfestasikan dengan $V$. lecanii secara buatan di laboratorium sebagai tambahan dari infestasi alami di lapangan.

Penelitian ini bertujuan untuk (1) mengevaluasi efikasi $V$. lecanii yang diinfesikan secara bautan untuk mengendalikan penyakit karat daun kopi di rumah dan (2) membandingkan keterjadian koloni $V$. lecanii pada daun sakit yang diinfestasi $V$. lecanii secara alami dan keterjadian koloni $V$. lecanii pada daun sakit yang sama tapi menerima infestasi buatan dengan antagonis di laboratorium.

\section{METODE PENELITIAN}

Penelitian ini dilaksanakan di rumah kaca dan laboratorium Fakultas Pertanian Universitas Lampung, Bandar Lampung, pada bulan Oktober 2005 sampai Januari 2006.

Penyiapan suspensi konidia $V$. lecanii. Untuk mendapatkan isolat $H$. vastatrix pribumi (native), sampel daun kopi yang menunjukkan bilur dan mengandung uredospora $H$. vastatrix dan koloni berwarna putih $(V$. lecanii) dipetik pada tanaman kopi di Sumberjaya, Lampung Barat. Daun yang dipilih ialah yang semuda mungkin yang telah mengandung bilur dan miselium $V$. lecanii agar tidak banyak terdapat mikroorganisme lain untuk memudahkan dalam isolasi $V$. lecanii. Masing-masing daun ditaruh dalam kantung plastik dan disimpan dalam termos berisi es selama transportasi ke laboratorium. Isolasi $V$. lecanii dilakukan dari sampel tersebut secara nirseptik dengan mengambil miselium berwarna putih tersebut dan menstransfernya ke cawan petri yang mengandung PDA-L (PDA yang ditambahkan $1.4 \mathrm{ml}$ 80\% asam laktat per L media). Inkubasi dilakukan pada suhu ruangan dengan periode cahaya 12:12 jam. Kultur murni dibuat dengan teknik ujung hifa (hyphal tips) dan disimpan pada agar miring yang mengandung media PDA.

Uji efikasi pada tanaman kopi di rumah kaca. Pada percobaan ini terdapat dua perlakuan, yaitu aplikasi suspensi konidia $V$. lecanii dan aquades steril sebagai kontrol masing-masing diulang enam kali. Unit percobaan berupa satu tanaman dalam pot. Konidia jamur $H$. vastatrix diproduksi dalam media nutrisi YMPD seperti yang dilaporkan Askary et al. (1997) dengan bahan-bahan per L media sebagai berikut: 3 g ekstrak ragi, 3 g malt, 5 g peptone-water, dan $10 \mathrm{~g}$ dekstrosa. Media cair ini digunakan untuk menumbuhkan jamur pada shaker pada kecepatan 120 rpm selama 7 hari. Pada akhir inkubasi kultur disaring dengan tiga lapis kain kasa steril untuk memperoleh suspensi konidia. Konsentrasi disesuaikan menjadi $10^{7}$ konidia per $\mathrm{ml}$ dengan aquades steril dengan menggunakan haemocytometer di bawah mikroskop.

Infestasi dengan agensia hayati dan inokulasi dengan patogen dilakukan dengan prosedur sebagai berikut. Tanaman kopi arabika setinggi kira-kira 70 cm disiapkan dalam pot berisi $5 \mathrm{~kg}$ tanah-kompospasir (2:1:1) pada meja semen (bench) di rumah kaca. Suspensi konidia agensia hayati $\left(10^{7} \mathrm{ml}^{-1}\right)$ yang sudah disiapkan disemprotkan dengan handsprayer sampai kedua permukaan daun basah. Setelah daun kopi kering udara (air dried), suspensi uredospora (4 x $10^{5}$ $\mathrm{ml}^{-1}$ ) disemprotkan secara merata pada permukaan bawah daun kopi sampai daun tersebut basah. Perlakuan kontrol ialah tanaman yang disemprot dengan aquades steril kemudian diinokulasi dengan suspensi uredospora.

Sebagai peubah diamati keparahan penyakit (disease severity) dengan menggunakan skor seperti pada Gambar 1 (Eskes, 1988 dalam Mawardi, 1996). Data diolah secara statistika dengan uji t. 


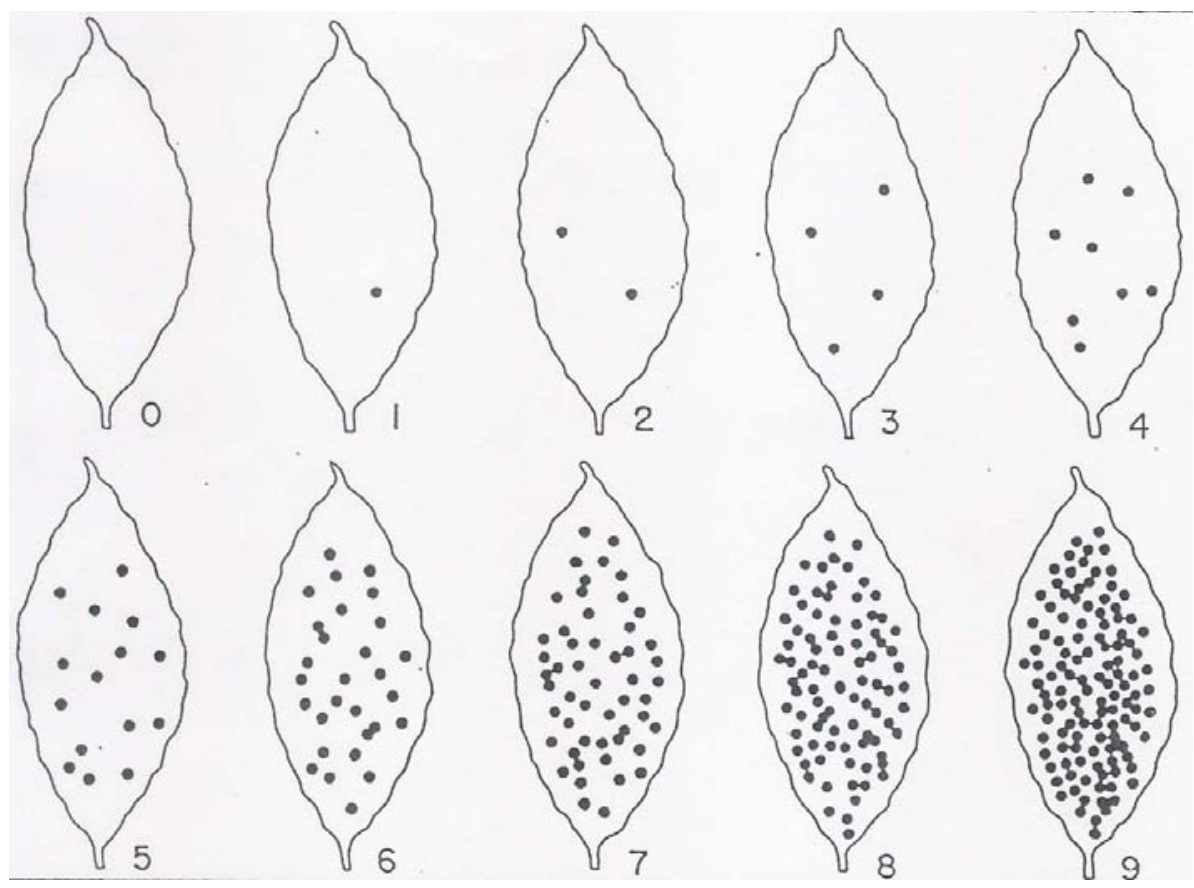

Gambar 1. Diagram penyakit karat daun sebagai dasar penentuan skor penyakit pada daun (Eskes, 1988 dalam Mawardi, 1996). Bergantung jumlah bilur (lesion), daun diberi skor 0 (tidak ada bilur) sampai 9 (jumlah bilur terbanyak).

\begin{abstract}
Aplikasi V. lecanii pada daun yang terinfestasi secara alami. Sepuluh pasang daun sakit diambil dari kebun kopi di Sumberjaya, Lampung Barat dan dibawa ke laboratorium dalam termos es. Satu bagian dari setiap pasang (10 lembar daun) diinkubasikan segera di laboratorium dan 10 yang lain diinfestasi dengan suspensi konidia $V$. lecanii terlebih dahulu baru diinkubasikan. Infestasi dilakukan dengan menyemprotkan suspensi konidia $\left(10^{7} \mathrm{ml}^{-1}\right)$ sampai semua permukaan bawah daun menjadi basah oleh suspensi tersebut. Peubah ialah keterjadian koloni $V$. lecanii pada bilur yang disebabkan oleh $H$. vastatrix pada daun kopi yang ditandai dengan adanya miselium yang berwarna putih pada bilur tersebut. Percobaan dilakukan dua kali, yaitu pada daun dengan keparahan penyakit yang relatif tinggi dan pada daun dengan keparahan penyakit yang relatif rendah. Pengamatan dilakukan 2 dan 4 hari setelah infestasi. Data keterjadian koloni $V$. lecanii pada bilur karat pada daun kopi dian alisis dengan uji t.
\end{abstract}

\section{HASIL DAN PEMBAHASAN}

Uji efikasi pada tanaman kopi di rumah kaca. Data hasil uji efikasi pada tanaman utuh di rumah kaca menunjukkan bahwa $V$. lecanii tidak menurunkan keparahan penyakit secara nyata kecuali data yang diperoleh pada minggu keempat (Tabel 1). Dilihat dari angka keparahan penyakit (Tabel 1), aplikasi suspensi konidia $V$. lecanii cenderung menurunkan keparahan penyakit kecuali pada minggu ke-3. Akan tetapi, uji statistika menunjukkan bahwa perbedaan tersebut tidak nyata kecuali pada minggu ke-4 pada saat keparahan penyakit pada tanaman yang diperlakukan dengan $V$. lecanii secara nyata lebih rendah $(P \leq 0,05)$ jika dibandingkan dengan yang terjadi pada tanaman kontrol. Data ini menunjukkan adanya penurunan keparahan penyakit meskipun tidak konsisten. Ketidakkonsistenan ini diduga terkait dengan dua hal, yaitu jangka waktu pengamatan dan faktor lingkungan. Jangka waktu pengamatan terkait dengan daur penyakit karat daun kopi. Aplikasi 
Tabel 1. Keparahan penyakit pada tanaman kopi yang diperlakukan dengan suspensi konidia $V$. lecanii dan tanaman kontrol di rumah kaca

\begin{tabular}{lccccc}
\hline \multirow{2}{*}{ Perlakuan } & \multicolumn{5}{c}{ Keparahan Penyakit (\%) $1-5$ Minggu setelah Inokulasi } \\
\cline { 2 - 5 } & 1 & 2 & 3 & $4^{1)}$ & 5 \\
\hline V. lecanii & 4,89 & 4,77 & 9,73 & 11,31 a & 17,36 \\
Kontrol & 5,59 & 5,32 & 9,42 & $12,83 \mathrm{~b}$ & 20,63 \\
T hitung & $0,24^{\text {tn }}$ & $0,25^{\text {tn }}$ & $0,10^{\text {tn }}$ & $0,41^{*}$ & $0,83^{\text {tn }}$ \\
\hline
\end{tabular}

${ }^{1)}$ Angka yang diikuti oleh huruf yang berbeda menunjukkan perbedaan secara nyata $(\mathrm{P} \leq 0,05)$.

suspensi konidia $V$. lecanii tidak diharapkan untuk mencegah infeksi oleh inokulum yang telah memenetrasi daun, tetapi diharapkan menurunkan potensi inokulum $H$. vastatrix sehingga inokulasi dan infeksi pada daur penyakit berikutnya menurun sehingga keparahan penyakit yang terjadi akan menurun. Dampak penurunan potensi inokulum yang mungkin terjadi terhadap daur penyakit berikutnya tidak diamati karena pendeknya jangka waktu pengamatan yaitu 5 minggu. Faktor lingkungan yang dimaksud terutama suhu yang relatif tinggi di rumah kaca karena penelitian berlangsung pada musim kemarau dan rumah kaca tidak dilengkapi dengan kipas angin. Suhu di rumah kaca pada siang hari mencapai $30-40{ }^{0} \mathrm{C}$, yang lebih tinggi dari suhu optimum untuk pertumbuhan $H$. vastatrix yakni $21-$ $15^{\circ} \mathrm{C}$ (Semangun, 2000). Hal ini mungkin menyebabkan rendahnya keparahan penyakit termasuk pada tanaman kontrol (Tabel 1). Keparahan penyakit yang rendah diduga menyebabkan kurang maksimalnya daya kontrol agensia hayati. Dengan demikian, penelitian serupa perlu dilakukan lagi dengan waktu pengamatan yang lebih lama dan upaya mengatur faktor lingkungan agar lebih mendukung perkembangan penyakit.

Aplikasi V. lecanii pada daun yang terinfestasi secara alami. Dua percobaan dilakukan untuk membandingkan keterjadian $V$. lecanii pada dua kelompok daun, yaitu daun yang terinfestasi antagonis secara alami tanpa infestasi buatan dan daun yang terinfestasi secara alami dengan infestasi buatan yaitu disemprot dengan suspensi konidia $V$. lecanii di laboratorium. Pada kedua percobaan tersebut, perlakuan tidak berpengaruh terhadap keterjadian $V$. lecanii (Tabel 2 dan 3).

Tabel 2 dan 3 menunjukkan bahwa $V$. lecanii secara alami berperan sebagai antagonis terhadap
$H$. vastatrix. Keterjadian koloni $V$. lecanii pada daun kopi dengan keparahan tinggi sebesar 49,63 dan 75,88\% masing-masing pada 2 dan 4 hari setelah infestasi (Tabel 2). Selain itu, keterjadian koloni $V$. lecanii pada daun kopi dengan keparahan rendah sebesar 14,17 dan 30,28\% masing-masing pada 2 dan 4 hari setelah infestasi (Tabel 3). Keberadaan antagonis tersebut pada bilur yang disebabkan oleh patogen pada daun kopi mengindikasikan bahwa antagonis ini berperan dalam pengurangan potensi inokulum di lapangan (Tabel 2 dan 3). Hal ini sejalan dengan keterangan pada Campbell (1989) bahwa secara umum antagonis pada permukaan daun menekan penyakit termasuk penyakit KDK. Lebih daripada itu, aplikasi fungisida khususnya yang berspektrum luas dapat mengurangi keefektifan antagonisme tersebut. Hal ini justru dapat meningkatkan intensitas penyakit. Campbell (1989) menunjukkan contoh kasus yaitu antagonisme $V$. lecanii terhadap $H$. vastatrix yang didasarkan atas laporan Mulinge and Griffits. Tanaman kopi yang disemprot tembaga, kaptafol, atau benomil pada tahun 1969 menurunkan penyakit pada tahun itu. Akan tetapi, jika tidak disemprot pada tahun berikutnya, tanaman itu terserang lebih berat jika dibandingkan dengan tanaman yang tidak disemprot pada 1969. Tanaman yang disemprot pada tahun 1969 harus disemprot lagi pada tahun 1970 agar penyakit karat daun kopi tetap terkendali. Hal ini menunjukkan dua hal: (1) terjadi penekanan penyakit oleh antagonis secara alami di lapangan dan (2) penyemprotan tanaman dengan fungsida menekan antagonis, selain mengendalikan penyakit, sehingga pada tahun berikutnya patogen berkembang tanpa hambatan oleh antagonis. Temuan tersebut menunjukkan pentingnya upaya untuk memelihara antagonis pada tanaman kopi. Melihat keberadaan $V$. lecanii pada bilur daun kopi dengan infenstasi secara alami, perlu diupayakan 
Tabel 2. Keterjadian koloni $V$. lecanii pada bilur daun kopi dengan keparahan karat daun relatif tinggi yang disemprot dengan suspensi konidia $V$. lecanii dan daun kontrol di laboratorium

\begin{tabular}{|c|c|c|}
\hline \multirow{2}{*}{ Perlakuan ${ }^{1)}$} & \multicolumn{2}{|c|}{ Keterjadian V. lecanii (\%) pada 2-4 hari setelah investasi } \\
\hline & 2 & 4 \\
\hline V. lecanii & 50,80 & 81,18 \\
\hline Kontrol & 49,63 & 75,88 \\
\hline T hitung & $0,13^{\mathrm{tn}}$ & $0,11^{\mathrm{tn}}$ \\
\hline
\end{tabular}

${ }^{1}$ Perlakuan $V$. lecanii ialah infestasi buatan di laboratorium di samping infestasi $V$. lecanii secara alami di lapangan, sedangkan perlakuan kontrol ialah infestasi alami tanpa infestasi buatan.

Tabel 3. Keterjadian koloni $V$. lecanii pada bilur daun kopi dengan keparahan karat daun relatif rendah yang disemprot dengan suspensi konidia $V$. lecanii dan daun kontrol di laboratorium

\begin{tabular}{lcc}
\hline \multirow{2}{*}{ Perlakuan } & \multicolumn{2}{c}{ Keterjadian $V$. lecanii (\%) pada 2-4 hari setelah investasi } \\
\cline { 2 - 3 } & 2 & 4 \\
\hline V. lecanii & 17,00 & 58,67 \\
Kontrol & 14,17 & 30,28 \\
T hitung & $0,07^{\text {th }}$ & $0,06^{\text {th }}$
\end{tabular}

${ }^{1}$ Perlakuan $V$. lecanii ialah infestasi buatan di laboratorium di samping infestasi $V$. lecanii secara alami di lapangan, sedangkan perlakuan kontrol ialah infestasi alami tanpa infestasi buatan.

untuk tidak menggunakan fungsida yang dapat menekan $V$. lecanii. Jika fungisida harus diaplikasikan, perlu dilakukan studi untuk memilih fungisida yang tidak merugikan peran agensia hayati ini di lapangan.

\section{SIMPULAN}

Aplikasi suspensi konidia $V$. lecanii cenderung menurunkan keparahan penyakit kecuali pada minggu ke-3. Uji statistika menunjukkan bahwa penurunan keparahan tersebut tidak nyata kecuali pada minggu ke-4.

Jumlah koloni $V$. lecanii pada bilur daun kopi akibat infestasi secara alami tidak berbeda nyata jika dibandingkan dengan koloni $V$. lecanii pada daun yang sama tapi menerima infestasi buatan dengan antagonis di laboratorium.

\section{SANWACANA}

Atas ketersediaan dana penelitian dari Proyek RUT XI, penulis menyampaikan terima kasih. Penulis juga menyampaikan terima kasih kepada Subli Mujim atas masukan dalam pelaksanaan penelitian di rumah kaca, kepada Rusdi Evizal atas masukan di lapangan, kepada Bapak Haji Wiyadi (alm.) dan keluarga yang mengizinkan penulis untuk memanfaatkan kebun kopinya di Sumberjaya Lampung Barat menjadi tempat penelitian, serta kepada Rizka Firdaus, Agus Ferdhinand, Tri Maryono, dan Farida Ariani atas bantuan teknis di laboratorium dan di lapangan.

\section{DAFTAR PUSTAKA}

Agrios, G.N. 2005. Plant Pathology. 5th Ed. Alsevier Academic Press, Burlington, MA. 922 pp.

Askary, H., N. Benhamou, \& J. Brodeur. 1997. Ultrastructural and cytochemical investigations of the antagonistic effect of $V$. lecanii on cucumber powdery mildew. Phytopathology 87:359-368.

Benhamou, N. \& J. Brodeur. 2000. Evidence for antibiosis and induced host reactions in the interaction between Verticillium lecanii and Penicillium digitatum, the causal agent of the causal agent of green mold. Phytopathology 90:932-943. 
Campbell, R. 1989. Biological Control of Microbial Plant Pathogens. Cambridge Univ. Press, Cambridge. 218 pp.

Ginting, C. \& S. Mujim. 2007. Efikasi Verticillium lecanii untuk Mengendalikan Penyakit Karat pada Cakram Daun Kopi di Laboratorium. J. HPT Trop. 7: 125 - 129.

Ginting, C., S. Mujim, \& A.H. Dianto. 2005. Isolasi spesies Verticillium yang berasosiasi dengan Hemileia vastatrix pada daun kopi. J. Natur Indonesia 8 (2): $114-117$.

Ginting, C., A. Gafur, \& R. Evizal. 2002. Beberapa hasil inokulasi pada cakram daun kopi dengan Hemileia vastatrix di laboratorium. J. HPT Trop. 2: $26-31$.

Kiss, L. 2003. A review of fungal antagonists of powdery mildews and their potential as biocontrol agents. Pest Manag. Sci. 59:475 483.
Mawardi, S. 1996. Kajian Genetika Ketahanan Tak Lengkap Kopi Arabika terhadap Penyakit Karat Daun (Hemileia vastatrix B. et Br.) di Indonesia. Disertasi. Universitas Gadjah Mada, Yogyakarta.

Mujim, S., R. Ruswandi, C. Ginting, \& R. Evizal. 2005. Asosiasi keterjadian koloni Verticillium dan intensitas naungan serta letak daun kopi. J. HPT Tropika 5:32-36.

Semangun, H. 2000. Penyakit-penyakit Tanaman Perkebunan di Indonesia. Edisi kedua. Gadjah Mada University Press, Yogyakarta. $835 \mathrm{hlm}$.

Yun, Y., P.D. Bridge, \& H.C. Evans. 1991. An integrated approach to the taxonomy of the genus Verticillium. J. Gen. Microbiol. 137:1437-1444. 